TEME, г. ХLII, бр. 3, јул - септембар 2018, стр. 741-761

Оригинални научни рад

DOI: $10.22190 /$ TEME1803741B

Примљено: 12. 7. 2017.

UDK 396:613.882-055.2:342.724

Ревидирана верзија: 7. 10. 2017.

Одобрено за штампу: 12. 6. 2018.

\title{
СТАВОВИ МЛАДИХ У СРБИЈИ ПРЕМА \\ ПРОСТИТУЦИЈИ, РОДНОЈ РАВНОПРАВНОСТИ И ФЕМИНИЗМУ У 2016. ГОДИНИ*
}

\author{
Драгица Богетић ${ }^{*}$, Јелена Митровић, Сандра Николић \\ Универзитет у Београду, \\ Факултет за специјалну едукацију и рехабилитацију, Београд, Србија \\ *dbogetic992@gmail.com
}

\begin{abstract}
Апстракт
Циљ истраживања био је да се испитају социо-демографски показатељи ставова младих у Србији према проституцији, родној равноправности и феминизму, те да се анализира однос ова три става међусобно, али и у односу на основне варијабле сексуалног понашања (узраст приликом првог сексуалног односа и број сексуалних партнера). Узорак истраживања је чинило 1114 испитаника (67,6\% женског пола, просечне старости 22,4 године, СД = 2,59). За прикупљање података коришћене су скала ставова о проституцији, скала ставова о родној равноправности (ЏамоњаИгњатовић, Жегарац, Поповић, \& Духачек, 2009) и скала ставова о феминизму (Џамоња-Игњатовић и сар., 2009). Резултати показују да младићи имају позитивнији став према проституцији, премда је разлика у односу на ставове девојака била далеко израженија у мањим него у већим местима. Супротно томе, подаци који се односе на ставове према родној равноправности и феминизму указују на то да девојке имају изражено позитивнији став у односу на младиће. Додатно, наши резултати показују да постоји позитивна повезаност ставова према родној равноправности и проституцији. Област регулисања права и социјалне заштите жена у проституцији у Србији је маргинализовано друштвено питање, а у друштвеној реакцији преовладава толеранција и индиферентност. Највећу вредност овог рада представљало би подизање свести научне и стручне јавности о важности усвајања родноравноправног дискурса који би у први план стављао увођење елемената права жена у проституцији и другачије системске регулативе у Србији. У том смислу би даље испитивање ставова о системским решењима, могућностима и изазовима у области проституције могло да представља значајан истраживачки допринос овој теми.

Кључне речи: проституција, родна равноправност, феминизам, ставови младих, Србија.
\end{abstract}

\footnotetext{
*Ауторке се искрено захваљују доц. др Предрагу Теовановићу на подршци и помоћи приликом израде рада.
} 


\title{
ATTITUDES OF YOUNG PEOPLE IN SERBIA ABOUT PROSTITUTION, GENDER EQUALITY AND FEMINISM IN 2016
}

\begin{abstract}
The objective of this research was to examine social and demographic predictors for the attitudes of young people in Serbia toward prostitution, gender equality and feminism, as well as to analyse the relations of these three attitudes between each other, and in relation to basic variable of sexual behaviour (age of first intercourse and number of sexual partners). The sample for this research was 1114 participants (67.6\% female with average age of 22.4 years, $\mathrm{SD}=2.59$ ). Three scales were applied in data collection process such as the scale of attitudes about prostitution, the scale of attitudes about gender equality (Džamonja-Ignjatović, Žegarac, Popović, \& Duhaček, 2009) and the scale of attitudes about feminism (Džamonja-Ignjatović et al., 2009). The results show that boys have more positive attitude about prostitution although the difference in regard to attitudes of girls was far more expressed in smaller than in big cities. Contrary to this, the data relative to the attitudes toward gender equality and feminism point that girls have expressed more positive attitude than boys. Additionally, our results show positive association of attitudes on gender equality and prostitution. The rights and social protection of women in prostitution in Serbia are a marginalised social issue and social reactions of tolerance and indifference are predominant. In this regard further research of attitudes of systematic solutions, possibilities and challenges in prostitution could provide significant contribution to this subject.
\end{abstract}

Key words: $\quad$ prostitution, gender equality, feminism, attitudes of young people, Serbia.

\section{УВОД}

Проституција је један од најстаријих друштвених феномена, који се може проучавати са различитих аспеката, док су за потребе овог истраживања најважнији политички, социјални и родни. Иако су савремена схватања о проституцији поларизована (Бјелајац \& Јовановић, 2012), једна група аутора залаже се за престанак посматрања овог феномена као једнодимензионалног, односно као бинарног (за легализацију или против легализације). У прилог томе, наглашавају мултидимензионалност феномена проституције, те указују на специфичност сваког сегмента на тржишту проституције, на њихову одвојену анализу и диференциране одговоре на политичком нивоу (Albert, Gomez, \& Franco, 2007).

Због непостојања конзистентног одређења проституције, аутори наводе кључне карактеристике овог феномена: комерцијализација сексуалних услуга, која се темељи на емоционалној индиферентности са здравственим ризиком, и промискуитетност (Милосављевић, 2003; Draženović, 2013). Приметна је различита правна регулација проституције у зависности од конкретног друштва - реглементацијом, која прописује правила надзора и редовне здравствене 
контроле, и прохибицијом, која забрањује и кажњава бављење проституцијом (Константиновић-Вилић, Николић-Ристановић, \& Костић, 2009). Посебно интересантном сматра се легислатива Шведске и Норвешке, где се криминализује куповина сексуалних услуга од особа које се баве проституцијом. Како су пружаоци услуга најчешће жене, одредбом су у значајно већој мери погођени мушкарци (Schulze, Novo Canto, Mason, \& Skalin, 2014). Овакав начин регулације проституције Норвешка и Шведска спроводе дуги низ година: Шведска од 1999. године, а Норвешка од 2009. године (Jakobsson \& Kotsadam, 2009), јасно имплицирајући освешћеност по питању родне димензије овог феномена. На листи од 144 земље, Норвешка заузима треће, а Шведска четврто место по питању имплементације родне равноправности (World Economic Forum, 2016). У односу на поменуте земље, глобални индекс родне равноправности Светског економског форума (2016) указује на то да се Србија налази на 48. месту (World Economic Forum, 2016). Слично као и са појмом проституције, родна равноправност у најважнијим европским документима није доследно дефинисана. Како би се превазишле тешкоће које произлазе из теоријских и концептуалних разлика, Европски институт за родну равноправност пружа опште одређење родне равноправности као ,једнаког удела у имовини и једнаког достојанства и интегритета између жена и мушкараца" (Бабовић, 2016: 11). Најновије измене 3aкона о јавном реду и миру (2016) указују на покушаје другачије легислативе проститиције у Србији, те наш законодавац део одговорности пребацује и на корисника сексуалних услуга. У члану 16 наводи ce: „Ко се одаје проституцији, користи услуге проституције или уступа просторије ради проституције - казниће се новчаном казном од 50.000 до 150.000 динара или казном затвора од 30 до 60 дана" („Сл. гласник РС”, 6/2016). Према тврдњама појединих ауторки, жене у проституцији у Србији једна су од најрањивијих и вишеструко дискриминисаних група које не уживају адекватну заштиту. Често су малтретиране и злоупотребљаване од стране макроа, корисника сексуалних услуга, полиције, те целокупног институционалног система, док су друштвена осуда и стигма неизоставни пратећи чиниоци (Стојаковић \& Петровић-Ранитовић, 2013). Додатно обесхрабрује то да као вишеструко дискриминисана група нису препознате у Националној стратегији за родну равноправност за период од 2016. до 2020. године („Сл. гласник РС”, 4/2016). У складу са изнетим чињеницама, мишљења смо да системска реакција у Србији на положај жена у проституцији не заузима довољно видљиво и значајно место у јавном, односно политичком, дискурсу.

Велики број истраживања спроведених на ову тему долазе до налаза да су мушкарци толерантнији и знатно више отворени према легализацији комерцијализације сексуалних услуга у односу на жене 
(Basow \& Campanile, 1990; Wu \& McCaghy, 1993; Cosby, May, Frese $\&$ Dunaway, 1996), укључујући и велику међународну студију спроведену у периоду од 2005. до 2007. године (Soo Chon, 2015), новија истраживања у нордијским земљама (Jóhannsdóttir, 2009; Jakobsson $\&$ Kotsadam, 2011) и истраживање о ставовима младих који су у систему високошколског образовања (Cotton, Farley \& Baron, 2002). Конзервативније ставове жена према проституцији потврђује и велико истраживање у коме су учествовали испитаници из 32 земље, а у које су били укључени и грађани Србије (Stack, Adamczyk, \& Cao, 2010). Истраживање спроведено у Сједињеним Америчким Државама о легализацији проституције показује да мушкарци испољавају чак два пута позитивније ставове у односу на жене (Мау, 1999). Слично претходном, резултати најновијег истраживања на ову тему у Канади указују на то да је пол значајан показатељ формирања ставова о де/криминализацији проституције (Cao, Lu, \& Mei, 2016). Наводи се да мушкарци имају израженију перцепцију могућности задовољавања сексуалних потреба користећи услуге проститутки, односно сексуалних радника и радница, у односу на жене, које значајно не увиђају ову могућност (Cotton et al., 2002).

Постоји мишљење да родне разлике у ставу о проституцији слабе у развијенијим срединама. Промене које се дешавају у складу са трансформационим процесима савременог друштва доводе до тога да традиционалне норме и пракса више нису у стању да се одупру порасту нове „космополитске културе” (Inglehart, Nevitte \& Basanez, 1996). У прилог овој тези говори и теорија модернизације, тврдећи да људски прогрес представља процес проширења човекове аутономије и слободе кроз борбу за права (Welzel, Inglehart, \& HansDieter, 2003; Welzel \& Inglehart, 2005). Ова теорија указује на то да постоји тренд ка већој толеранцији различитих начина живота у социјално и економски напреднијим земљама и срединама (Сао \& Selman, 2010). Томе треба додати резултате истраживања спроведеног у скандинавским земљама који показују да се овакав тренд односи само на мушки пол. Наиме, мушкарци који су сексуално либералнији и који су имали већи број сексуалних партнера имају и позитивнији став према проституцији (Jakobsson \& Kotsadam, 2009, 2011).

Према мишљењу Со Чон (Soo Chon, 2015), не може се изнети уопштена тврдња о односу између става о проституцији и родној равноправности јер истраживања у различитим земљама не дају истоветне резултате. Наиме, индивидуални ставови о проституцији и родној равноправности директно зависе од тога из које земље потичу испитаници, а те разлике могу бити и одраз различитих феминистичких погледа на проституцију. Томе треба додати да на став о проституцији значајно може утицати ниво економског развоја земље и индекс родне равноправности (Soo Chon, 2015). Овакве налазе мо- 
жемо повезати и са бољом рангираношћу земаља по питању залагања за родну равноправност (Шведска, Норвешка) и њиховом ранијом инкриминацијом куповине сексуалних услуга (World Economic Forum, 2016).

Обичаји, право, класна и етничка припадност, као и предрасуде раширене у датом друштву - подједнако утичу на формирање улога мушкараца и жена (Бркић \& Несторовић, 2011). Стек и сарадници (Stack et al., 2010) тврде да култура једне земље има битан утицај и на формирање односа према проституцији. У том смислу, будућим истраживачима ове области препоручује се да са већом прецизношћу идентификују и тестирају културу државе у којој се истраживање обавља.

Према домаћој феминистичкој ауторки (Захаријевић, 2008), на феминизам се може гледати као на покрет, идеологију, мрежу теоријских позиција и скуп различитих активности чији је циљ укупно побољшање положаја жена. С обзиром на комплексност самог појма, феминизам није лако захватати једном дефиницијом. Станфордска енциклопедија филозофије (Stanford Encyclopedia of Philosophy) нуди уводно објашњење термина феминизма као „интелектуалне обавезе и политичког покрета који тражи правду за жене и крај сексизма у свим његовим облицима" (Haslanfer, Tuana, \& O'Connor, 2012).

У многим феминистичким дискусијама постоји дискрепанца између становишта која заговарају тезу да је жена слободна да са својим телом ради шта жели и оних који, насупрот њему, тврде да је проституцијом женско тело мушкарцима доступно у било ком тренутку, те је објективизацијом женског тела често заступљено и насиље (Schulze et al., 2014). Међу феминисткињама постоје различита схватања о томе шта доводи до женске подређености, које су конструктивне методе за мењање позиције жена и на који начин уредити родне односе у праведном друштву (Мијатовић, 2008).

Нетрадиционалне родне улоге и феминизам директно се супротстављају устаљеном родном поретку, који на стереотипан начин посматра родне улоге. Сматра се и да образовање има битне ефекте на ставове према феминизму, јер омогућава излагање и утицај егалитарних идеја и спречава усвајање и прихватање родних митова и стереотипа (Davis \& Robinson, 1991; Cassidy \& Warren, 1996; Rhodebeck, 1996; Brooks \& Bolzendahl, 2004). Код жена са вишим степеном образовања постоје веће шансе за каријерним амбицијама и стога се сматра да може имати већи утицај на залагање за родну равноправност, те елиминисање родне дискриминације.

Међу истраживањима ставова према феминизму, има аутора који посебно наглашавају улогу образовања мајке, као важног чиниоца социјализације, за формирање позитивних ставова према феми- 
низму, те је посредована ефектом пола и односи се претежно на женску децу (Tallichet \& Willits, 1986; Bolzendahl \& Myers, 2004). Треба истаћи и запажање других аутора, према којима се узрок негативнијих ставова мушкараца према феминисткињама и нетрадиционалним облицима изражавања рода може тражити у нескладу идентититета родних улога, који је супротстављен „идеалу наглашеног маскулинитета и феминитета" (Toller, Suter, \& Trautman, 2004: 85). Међутим, треба истићи и критику овог приступа због „упадања у замку есенцијализма", који појачава стереотипе и организацију родне поделе улога у савременом друштву (Fraser, 1997, према: Бабовић, 2016: 12).

\section{Предмет и ичиљ истраживања}

Истраживање је имало за циљ да испита социо-демографске корелате ставова младих у Србији према проституцији, родној равноправности и феминизму. Први задатак био је да се провере метријске карактеристике три скале ставова, при чему су две преузете из ранијих истраживања (родна равноправност и феминизам; Џамоња-Игњатовић и сар., 2009), док је једна скала конструисана за потребе самог истраживања (скала ставова према проституцији). Други задатак био је да се испита да ли, и уколико да, на који начин, испитани ставови зависе од пола, места одрастања и узраста испитаника. На крају, сматрали смо да је значајно проверити у каквом су односу ова три става, као и да ли постоји њихова повезаност са основним варијаблама сексуалног понашања, као што су узраст приликом првог сексуалног односа и број сексуалних партнера. Испитивањем повезаности става према проституцији (залагање за бољу правну регулативу у земљи, адекватнију здравствену и социјалну заштиту жена у проституцији, мању друштвену стигму и социјалну дистанцу) и става према родној равноправности и феминизму, желели смо да истражимо постојање повезаности између залагања за бољи положај жена уопште и у проституцији.

\section{МЕТОД \\ Узорак}

Узорак истраживања је чинило 1114 испитаника $(67,6 \%$ женског пола и $32,4 \%$ мушког пола). Просечна старост испитаника била je 22,4 године $(S D=2,59)$. На основу података о месту одрастања, испитаници су подељени у три групе: село $(8,8 \%)$, мањи град $(19,1 \%)$ и већи град $(71,7 \%)$. Пол и место одрастања нису били повезани у нашем узорку $\left(\chi^{2}(2)=0,63, p=0,73\right)$.

Просечан узраст на ком испитаници извештавају да су ступили у први сексуални однос износи 17,67 година $(S D=2,02)$, при 
чему је он био значајно виши $(t(1074)=3,65, p<0,001)$ код девојака $(M=17,83, S D=1,95)$ него код младића $(M=17,35, S D=2,13)$, док разлике с обзиром на место одрастања нису биле значајне $(F(2,1070)$ $=0,09, p=0,91$ ).

Место одрастања није било статистички значајан показатељ ни броја сексуалних партнера $(F(2,1097)=0,71, p=0,49)$, али је и у овом истраживању добијен податак да младићи наводе да су имали статистички значајно $(t(1102)=6,58, p<0,001)$ више сексуалних партнера $(M=7,08, S D=8,89)$ у односу на девојке $(M=4,31, S D=5,05)$.

\section{Варијабле и инструменти}

Упитник. Социо-демографски подаци (пол, узраст и место одрастања) и информације о сексуалном понашању (узраст приликом првог сексуалног односа и број сексуалних партнера) прикупљени су путем упитника који је посебно конструисан за потребе истраживања.

Поред тога, испитаници су одговарали и на три скале ставова, и то изражавањем степена слагања са различитим тврдњама путем петостепене скале Ликертовог типа.

Скала ставова према проституцији. Посебно је конструисана за потребе овог истраживања и садржи 14 питања (нпр.: „Проституција би требало да буде правно регулисана као и свако друго занимање јер би на тај начин држава имала профит, а особе које се баве проституцијом редовну здравствену и социјалну заштиту.”). Према сазнањима ауторки, до тренутка спровођења истраживања, у домаћој литератури није коришћена скала ставова према проституцији која би испунила потребе и циљеве овог истраживања. Главни недостатак ове скале односи се на претходно неутврђену поузданост и дискриминативност путем спровођења пилот-истраживања, али резултати спроведеног истраживања указују на задовољавајуће метријске карактеристике скале ставова према проституцији (Табела 1).

Скала ставова према родној равноправности (ЏамоњаИгњатовић и сар., 2009). Састоји се из три супскале (ставови према породичним улогама, ставови према партнерским улогама и ставови према професионалној/јавној делатности) и укључује ставке попут „Отац треба да буде већи ауторитет за децу од мајке”, „За партнерско насиље су подједнако одговорна оба партнера”, „Мушкарци имају више смисла за бављење науком".

Скала ставова према феминизму (Џамоња-Игњатовић и сар., 2009). Ова скала садржи само три питања (нпр.: „Феминисткиње су агресивније од других жена.”), што представља главно ограничење. Како у научном дискурсу не постоји слагање о јединственој дефиницији феминизма и феминисткиња (Захаријевић, 2008), други недостатак ове скале може се пронаћи и у претпоставци да се у лаичком схватању ови појмови посматрају на различите начине. 


\section{Поступак прикупљања података}

За задавање описаних инструмената коришћена је Google Forms платформа. Истраживање је оглашено путем друштвених мрежа и личних контаката ауторки истраживања. Прикупљање података спроведено је током јануара 2016. године. Поступак прикупљања података за потребе истраживања има недостатке у погледу немогућности свеобухватне контроле социо-демографских варијабли испитаника.

\section{РЕЗУЛТАТИ}

Дистрибуиије скорова и метријске одлике скала

У Табели 1 приказани су резултати дескриптивних анализа података добијених применом три скале на нашем узорку. Поред тога, табела приказује и резултате Колмогоров-Смирнов теста нормалности расподеле скорова, те мере поузданости скала под Кронбаховим и Гутмановим моделима релијабилности.

Табела 1. Расподела скорова, дискриминативност и поузданост скала ставова

\begin{tabular}{|c|c|c|c|c|c|c|c|}
\hline \multirow[b]{2}{*}{ Став } & \multicolumn{3}{|c|}{$\begin{array}{c}\text { Дескриптивна } \\
\text { статистика }\end{array}$} & \multicolumn{2}{|c|}{ Дискриминативност } & \multicolumn{2}{|c|}{ Поузданост } \\
\hline & Распон & $\mathrm{M}$ & SD & $\mathrm{KS} \mathrm{Z}^{\mathrm{a}}$ & $\mathrm{p}$ & $\alpha^{b}$ & $\lambda^{\mathrm{c}}$ \\
\hline $\begin{array}{l}\text { Родна } \\
\text { равноправност }\end{array}$ & $1,47-5,00$ & 3,56 & 0,59 & 1,18 & 0,13 & 0,78 & 0,77 \\
\hline Феминизам & $1,00-5,00$ & 3,61 & 0,98 & 3,09 & $<0,001$ & 0,72 & 0,74 \\
\hline Проституција & $1,21-5,00$ & 3,37 & 0,72 & 1,76 & $<0,01$ & 0,80 & 0,80 \\
\hline
\end{tabular}

Иако теже средњим теоријским вредностима, просечне вредности на скалама ставова, приказане у трећој колони Табеле 1, померене су у извесном степену удесно, ка позитивнијем ставу. Компаративно посматрано, мере става према проституцији су у просеку биле значајно ниже у односу на мере става према родној равноправности $(t(1113)=8,48, p<0,001)$ и става према феминизму $(t(1113)=$ $7,16, p<0,001)$, док се просеци на последње две скале нису значајно разликовали $(t(1113)=1,94, p>0,05)$.

Приказани резултати указују и на задовољавајући варијабилитет скорова испитаника на све три скале. Наиме, у сва три случаја емпиријски распон скорова је готово у потпуности одговарао теоријском. Ипак, само је на скали ставова према родној равноправности регистрована емпиријска расподела која не одступа статистички значајно од 
нормалне $(Z=1,18, p=0,13)$, док су дистрибуције скорова на скалама ставова према фенимизму и проституцији показале значајна одступања од модела нормалне расподеле $(p<0,01)$. Даља анализа показује да је емпиријска дистрибуција на скали става према феминизму негативно асиметрична $\left(S k=-0,38, S E_{S k}=0,07\right)$ и платикуртична $\left(K u=-0,42, S E_{K u}=\right.$ $0,15)$, а сличне налазе региструјемо и на скали става према проституцији $\left(S k=-0,20, S E_{S k}=0,07 ; K u=-0,64, S E_{K u}=0,15\right)$.

На крају, резултати приказани у последње две колоне Табеле 1 указују на задовољавајућу поузданост мерења три става на испитиваном узорку испитаника, како под Кронбаховим $(\alpha s>0,70)$ тако и под Гутмановим моделом $(\lambda s>0,70)$. Највише вредности коефицијената поузданости регистроване су на скали става према проституцији, а занимљив је и податак да скала ставова према феминизму има релативно висок ниво поузданости иако садржи само три питања. Приказани резултати указују на задовољавајуће метријске карактеристике скала ставова које су коришћене у овом истраживању.

\section{Полне разлике на скалама ставова}

У Табели 2 приказани су дескриптори расподеле скорова на три скале ставова за подузорке младића $(\mathrm{n}=361)$ и девојака $(\mathrm{n}=$ 753), као и резултати тестова значајности разлика њихових просека.

Табела 2. Полне разлике на скалама ставова

\begin{tabular}{lccccc}
\hline Став & Пол & $\mathrm{M}$ & $\mathrm{SD}$ & $\mathrm{t}(1112)$ & $\mathrm{p}$ \\
\hline \multirow{2}{*}{ Родна равноправност } & Женски & 3,63 & 0,57 & \multirow{2}{*}{6,05} & \multirow{2}{*}{ \0,001 } \\
\hline \multirow{2}{*}{ Феминизам } & Мушки & 3,40 & 0,61 & & \\
\hline \multirow{2}{*}{ Проституција } & Женски & 3,84 & 0,89 & \multirow{2}{*}{12,26} & $<0,001$ \\
\hline & Мушки & 3,12 & 0,98 & & \\
\hline
\end{tabular}

Резултати указују на то да се младићи и девојке разликују у односу на све три скале ставова. Највећа разлика уочена је на скали феминизма, и то у корист девојака $(d=0,76)$. Слично томе, девојке имају позитивнији став и према родној равноправности у односу на младиће $(d=0,39)$. На скали става према проституцији региструјемо сасвим супротну тенденцију. Наиме, у овом случају значајно позитивнији став уочавамо код младића $(d=-0,34)^{1}$.

\footnotetext{
${ }^{1}$ Непараметријски тестови значајности разлика дају исте резултате и на скали ставова према феминизму $(U=79625, p<0,001)$ и на скали ставова према проституцији $(U=108058, p<0,001)$.
} 


\section{Место становања као показатељь испитиваних ставова и као модератор ефекта пола}

Резултати једнофакторске анализе варијансе показују да место одрастања испитаника одређује њихов став према родној равноправности $(F(2,1107)=5,77, p=0,003)$. Применом Шефеовог post hoc теста регистрована је статистички значајна разлика $(p<0,05)$ између испитаника који су одрастали у селу $(M=3,41)$ и оних који су одрастали у већем граду $(M=3,59)$. Увођењем пола као другог фактора у анализу варијансе није регистрована значајна интеракција места одрастања и пола у њиховом деловању на став према родној равноправности, што указује на то да је разлика између испитаника из села и већег града слична на подузорцима младића и девојака.

Примена Краскал-Волисовог теста показује да место одрастања испитаника није значајан показатељ нити става према феминизму $(H=1,74, p=0,42)$, нити става према проституцији $(H=4,73, p=$ $0,09)$. Међутим, укључивањем места одрастања као другог фактора у анализу варијансе у којој се пол користи као показатељ става, добијају се значајни ефекти интеракције пола и места одрастања, како у случају става према феминизму $(F(2,1104)=3,10, p=0,046)$ тако и у случају става према проституцији $(F(2,1104)=3,68, p=0,026)$.

На Слици 1 приказане су просечне вредности на скали феминизма за младиће и девојке у групама формираним с обзиром на величину места одрастања, уз интервале поверења од 95\%. Иако је у све три групе приметна разлика у просечним вредностима на скали феминизма између девојака и младића, полне разлике нису биле значајне када је као место одрастања наведено село $(d=0,24, p=0,05)$. У преостала два случаја, разлика је била статистички значајна у том смислу да су девојке показивале значајно позитивније ставове према

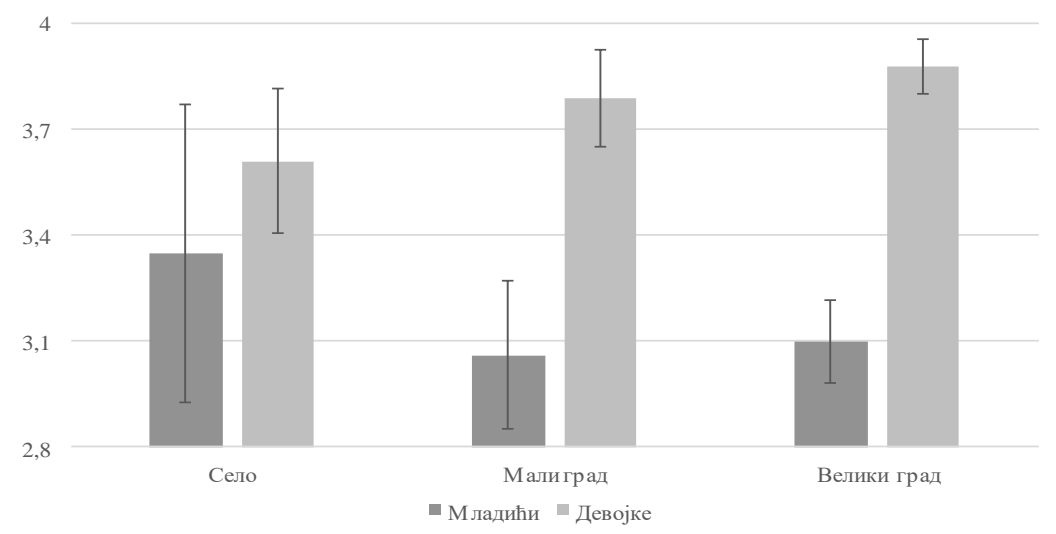

Слика 1. Ставови према феминизму у односу на пол и место одрастања 
феминизму и у односу на подгрупу младића који су одрасли у мањем граду $(d=0,84, p<0,001)$, и у односу на подгрупу младића који су одрасли у већем граду $(\mathrm{d}=0,83, p<0,001)$.

Супротно претходном, разлике између младића и девојака у њиховом ставу према проституцији биле су најизраженије у случају када је као место одрастања наведено село $(d=0,89, p<0,001)$. Иако су младићи доследно показивали значајно позитивније ставове према проституцији у односу на девојке (видети Слику 2), разлика у њиховом ставу била је осетно нижа у малим $(d=0,48, p=0,002)$, а нарочито нижа у великим градовима $(d=0,24, p=0,001)$.

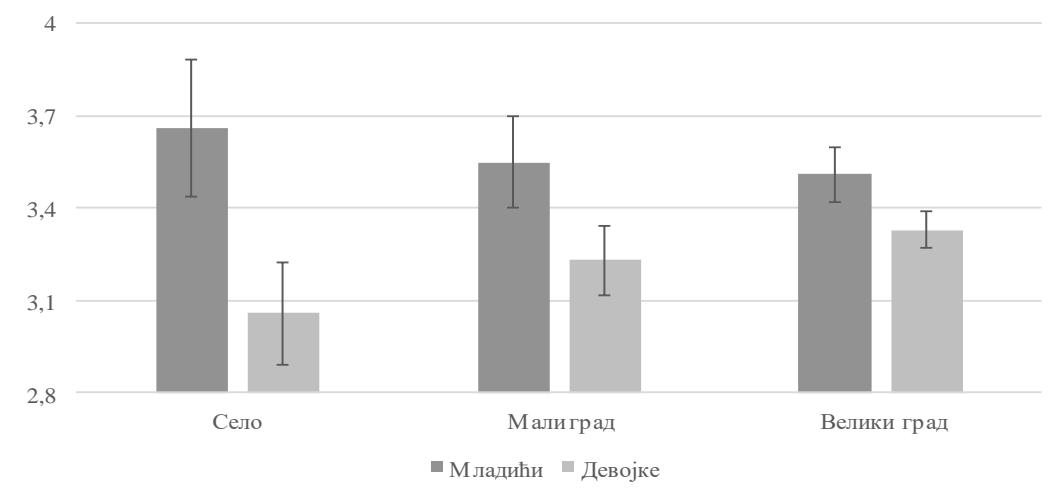

Слика 2. Ставови према проституиији у односу на пол и место одрастања

\section{Повезаност ставова са питањима која се односе на сексуално понамане}

Коначно, испитали смо какав је однос скорова на скалама ставова према родној равноправности, феминизму и проституцији, како међусобно тако и у односу на узраст, године првог сексуалног искуства и број сексуалних партнера. Резултати ових анализа приказани су у Табели 3 .

Табела 3. Корелаиије скорова на скалама ставова, узраста и сексуалног понашања

\begin{tabular}{|c|c|c|c|c|c|}
\hline Варијабла & 1 & 2 & 3 & 4 & 5 \\
\hline 1. Родна равноправност & I & & & & \\
\hline 2. Феминизам & $0,50^{* * * *}$ & I & & & \\
\hline 3. Проституција & $0,37^{* * *}$ & $0,17^{* * *}$ & I & & \\
\hline 4. Узраст & $0,06^{*}$ & $-0,01$ & $0,11^{* *}$ & / & \\
\hline 5. Први однос (узраст) & $0,08^{* *}$ & $0,08^{* * *}$ & $-0,07^{*}$ & $0,23^{\text {**** }}$ & I \\
\hline 6. Број сексуалних партнера & $-0,08^{* *}$ & $-0,12^{* * * *}$ & $0,17^{* * *}$ & $0,25^{* * * *}$ & $-0,41^{* * * *}$ \\
\hline
\end{tabular}


Резултати показују да су ставови према родној равноправности високо и позитивно повезани са ставовима према феминизму $(r=0,50, p<0,001)$, док су умерено повезани са ставовима према проституцији $(r=0,37, p<0,001)$. Корелација између ставова према феминизму и проституцији је, премда статистички значајна, била ниског интензитета $(r=0,17, p<0,001)$.

Ниске позитивне везе регистроване су и између става према проституцији, са једне стране, и узраста $(r=0,11, p<0,01)$ и броја сексуалних партнера $(r=0,17, p<0,001)$, са друге стране. Слични обрасци корелација регистровани су у обе групе испитаника формиране с обзиром на пол, као и у све три групе испитаника формиране с обзиром на место одрастања.

\section{ДИСКУСИЈА}

Налаз по којем младићи имају позитивније ставове према проституцији у односу на девојке у складу је са резултатима ранијих истраживања (Basow \& Campanile, 1990; Wu \& McCaghy, 1993; Cosby et al., 1996; May, 1999; Cotton et al., 2002; Jóhannsdóttir, 2009; Stack et al., 2010; Jakobsson \& Kotsadam, 2011; Soo Chon, 2015; Cao et al., 2016). Референтни аутори за разлозима робусног ефекта пола на ставове према проституцији трагају у различитим изворима, као што су конзервативнији ставови жена према сексуалним активностима уопште (Basow \& Campanile, 1990) или полне разлике у перцепцији о могућности задовољења сексуалних потреба путем услуга проститутки (Cotton et al., 2002). Разлози за позитивније ставове мушкараца према проституцији могу се крити и у простој чињеници да међу корисницима има знатно више припадника мушког пола, док међу особама које се баве проституцијом има неупоредиво више жена. Негативнији ставови жена према проституцији могу бити и израз већег степена свесности и опреза у погледу полно преносивих болести и промискуитетног сексуалног понашања, али и родне сензитивности и дубљег разумевања укупне изложености насиљу и виктимизацији. Коначно, могуће је и да мушкарци више верују у тзв. „митове о проституцији", у који спада и онај да жене које се баве проституцијом заправо уживају у свом послу, да су га добровољно изабрале и да помоћу њега лако зарађују новац (Cotton et al., 2002).

Треба имати у виду и да је проституција шири појам од уличне проституције, са којом се обично поистовећује, те да обухвата и друге облике активности, као што су телефонска проституција, еротске масаже, еротски плес и слично (Weitzer, 2000). У прилог томе говоре и резултати једног канадског истраживања који показују да улична проституција чини само $20 \%$ укупне проституције у овој држави (Cool, 2004). У том контексту, могло би се претпоставити да му- 
шкарци у просеку имају шире схватање појма проституције у односу на жене. Супротно томе, жене чешће поистовећују целокупну проституцију са уличном, која се због изложености вишеструкој виктимизацији сматра најризичнијим обликом проституције (Månsson, 2004). На крају, закључујемо да су овакве супротности у перципирању доминантних типова проституције могући извори полних разлика у ставовима према проституцији.

Резултати нашег истраживања показују и да је разлика између младића и девојака у погледу ставова према проституцији била далеко израженија у мањим него у већим местима. Такав налаз у складу је са разматрањима према којим полне разлике у ставовима према проституцији слабе у економски развијенијим и вредносно либералнијим срединама (Inglehart et al., 1996). Све негативнији ставови мушкараца у већим местима могу се сагледати као показатељ већег степена разумевања социјалних и економских околности у којима су жене довођене у позицију да се баве нерегулисаним облицима проституције и ризицима које такве активности носе. Са друге стране, све позитивнији ставови жена према проституцији у већим местима могу се разумети и као израз еманципације од традиционалних модела родних улога. У складу са тим је и налаз о позитивној повезаности између става о проституцији и броја сексуалних партнера, при чему су различити обрасци регистровани с обзиром на пол испитаника. Док на подузорку младића суштински не постоји веза између броја сексуалних партнера и става према проституцији, она је регистрована на подузорку девојака - већи број сексуалних партнера био је у вези са позитивнијим ставовима девојака према проституцији. Није згорег поменути и интересантне податке истраживања (Sawyer, Metz, Hinds, \& Brucker, 2001) по којем позитивније ставове према проституцији имају мушкарци, и то они који су користили услуге проституције. Позитивнији ставови девојака према теми родне равноправности добијени на нашем узорку у складу су са резултатима новијих истраживања у региону (Докмановић, 2012; Blažev, Jugović, Rimac, \& Blažev, 2016). Може се претпоставити да је разлог томе борба за равноправност полова која директно имплицира бољи положај жена како у радној и образовној сфери тако и у систему остваривања једнаких права и заштите на свим пољима.

Како деловања социјалне средине могу имати битну улогу у формирању родно равноправних ставова тако и резултати нашег истраживања указују на веће подржавање родне равноправности младића који су одрастали у већим градовима у односу на оне из мање урбаних и руралних средина. Урбана окружења обезбеђују већу хетерогеност у могућностима и изборима информисања, те идеологијама (Bolzendahl \& Myers, 2004). 
Надаље, резултати нашег истраживања показују да девојке имају позитивнији став и према феминизму, што потврђују и налази других истраживања (Davis \& Robinson, 1991, према: Bolzendahl \& Myrs, 2004; Cree \& Dean, 2015). Оно што је занимљиво, међутим, јесте налаз по којем је ефекат пола на ставове према феминизму модериран величином места одрастања. И док у селима не постоје значајне разлике између младића и девојака у њиховим ставовима према феминизму, ове разлике постају изражене у малим и великим градовима. Може се претпоставити да су у руралним срединама родне улоге ригидније, а тема феминизма од мањег значаја за живот. Са већом флексибилношћу родних улога и израженијим позитивним ставовима према родној равноправности, посебно у подузорку девојака из већих места, теме као што су сексуалне слободе и радна права добијају на значају и постају тачка дијалога између полова. Поједини аутори објашњавају подржавање феминистичких ставова са становишта интересних структура, када интересне групе имају користи од идеологије равноправности полова. Стога, није изненађење да у просеку жене чешће фаворизују равноправност него мушкарци, јер овакво опредељење и залагање има за циљ да обезбеди директне користи за женски пол, као што су, на пример, елиминисање или смањивање дискриминације по питању накнада за посао (Davis \& Robinson, 1991, према: Bolzendahl \& Myrs, 2004).

Резултат о позитивној повезаности ставова према родној равноправности и проституцији у супротности је са налазима међународне студије у којој се закључује да је снажно подржавање родне равноправности повезано са негативнијим ставом према проституцији (Soo Chon, 2015). До оваких резултата су дошли како истраживачи у Кини (Cao \& Stack, 2010) тако и истраживачи на подручју Шведске и Норвешке (Jakobsson \& Kotsadam, 2011). Разлика наведених резултата и нашег могла би се делом објаснити разликама у правним регулативама земаља, али и у развијености феминистичких и родноравноправних струја у друштву. Како у нашој држави системске реакције нису засноване на активностима којима се регулише питање социјалне, здравствене и правне заштите особа које се баве проституцијом, усвојеност или поштовање родно равноправних ставова могло би да укаже на тежњу грађана ка хуманијој оријентацији, односно обрасцима мишљења и понашањима која искључују дискриминацију и омогућавају солидарност у могућностима и начинима постизања циљева најразличитијих делова популације. На то указује и садржај коришћене скале ставова према проституцији, која је укључивала и тврдње које се односе на промену законске регулативе у нашој земљи, и недискриминишући приступ према особама које се баве проституцијом. Иако резултати о повезаности ставова према феминизму и проституцији потврђују раније налазе (Basow \& Campanile, 
1990; Cao \& Stack, 2010; Cao et al., 2016), треба имати у виду да се феминистички погледи на проституцију и положај жена у проституцији драстично разликују. Према ставовима радикалних феминиста, слобода личности жена је потпуно спутана, сексуалност негирана, а проституција се види као сексуално ропство и полно основана принуда мушкарца над женом, што производи ставове криминализације. Вредносни ставови умерених феминиста се у великој мери разликуjу. Слободна воља у бављењу проституцијом може да постоји, док главни проблем виде у стигматизацији друштва и праве поделу између слободне проституције, која представља сексуални рад, и принудне проституције, коју виде као сексуално искоришћавање. Није згорег споменути и схватања либералних феминиста, који на проституцију гледају као на облик рада, те се залажу за нормативно регулисање проституције (Overall, 1992).

\section{ЗАКЉУЧАК}

Тема повезаности ставова према проституцији, родној равноправности и феминизму, према нашим сазнањима, до сада није разматрана у домаћој литератури. Област регулисања права и социјалне заштите жена у проституцији у Србији је маргинализовано друштвено питање, а у друштвеној реакцији преовладавају толеранција и индиферентност.

Како би се боље сагледало стање у нашој земљи по питању феномена које смо испитивале, овде бисмо се осврнуле на резултате низа истраживања о положају жена, који представљају основу за Националну стратегију за родну равноправност за период од 2016. до 2020. године. Главни закључци указују на то да је укупан друштвеноекономски положај жена знатно гори у односу на положај мушкараца, те да постоји диспаритет прокламованих принципа и конкретне праксе у спровођењу политика, иако мушкарци и жене у Србији, формално гледано, имају једнака права. Нарочито бисмо истакле да се у Стратегији ставља акценат на елиминисање сваке врсте дискриминације и побољшање положаја вишеструко вулнерабилних жена, при чему се наводе различите рањиве категорије жена, али експлицитно нису идентификоване жене које се баве проституцијом. Зато, напомињемо да Закон о забрани дискриминаиије („Сл. гласник РС”, број 22/09) обавезује државу да спроводи свеобухватне мере спречавања и заштите вишеструке дискриминације, која је описана као тежак облик дискриминације (члан 13, тачка 5), те би морала да идентификује све рањиве групе.

У том смислу, наши резултати потврђују тезу ауторке ЂурићКузмановић (2010) којом указује да владајућа елита у Србији није довољно родно осетљива, те да не препознаје дискриминацију у сфери 
проституције. Разлози континуирано лошег положаја жена у Србији бројни су: од општег осиромашења друштва до неравноправне расподеле моћи у корист мушкараца.

Највећу вредност овог рада представљало би подизање свести научне и стручне јавности о важности усвајања родно равноправног дискурса који би у први план стављао увођење елемената права жена у проституцији и другачије системске регулативе у Србији. У том смислу би даље испитивање ставова о системским решењима, могућностима и изазовима у области проституције могло да представља значајан истраживачки допринос овој теми.

\section{ЛИТЕРАТУРА}

Albert, R., Gomez, F., \& Franco, Y. G. (2007). Regulating prostitution: A comparative law and economics approach. DOCUMENTO DE TRABAJO, 2007, 30. Доступно на http://documentos.fedea.net/pubs/dt/2007/dt-2007-30.pdf, приступљено 8.7. 2017.

Бабовић, М. (2016). Индекс родне равноправности у Републици Србији: Мерење родне равноправности у Србији 2014. години [Gender equality index in the Republic of Serbia: Measurement of gender equality in Serbia in 2014]. Београд: Влада Републике Србије, Тим за социјално укључивање и смањење сиромаштва. Доступно на http://socijalnoukljucivanje.gov.rs/wpcontent/uploads/2016/02/Izvestaj_Indeks_rodne_ravnopravnosti_2016_SRP.p df, приступљено 20. 9. 2017.

Basow, S. A., \& Campanile, F. (1990). Attitudes toward prostitution as a function of attitudes toward feminism in college students: An exploratory study. Psychology of Women Quartely, 14(1), 135-141. doi:10.1111/j.1471-6402.1990.tb00009.x

Бјелајац, Ж., Јовановић, М. (2012). Улога религије у развоју и сузбијању проституције [The role of religion in the development and suppression of prostitution]. Култура полиса, 19, 163-183. Доступно http://kpolisa.com/ KP19/kp19-III-4-BjelajacJovanovic.pdf, приступљено 20. 9. 2017.

Blažev, D., Jugović, I., Rimac, I., \& Blažev, M. (2016). Važnost stereotipa i uvjerenja o rodnim ulogama u objašnjenju stavova prema lezbijkama i gejevima [The Importance of Stereotypes and Beliefs about Gender Roles in Explaining Attitudes Towards Lesbians and Gays]. Zadar: 20. Dani psihologije u Zadru. Доступно http://www.unizd.hr/Portals/29/2016/XX\%20Dani\%20psihologije\%20u\%20Z adru\%20-\%20Summaries-sazetci.pdf?ver=2016-05-30-061019-427, приступљено 8. 7. 2017.

Bolzendahl, C., \& Myers, D. J. (2004). Feminist Attitudes and Support for Gender Equality: Opinion Change in Women and Men, 1974-1998. Social Forces, 83(2), 759-789. doi:10.1353/sof.2005.0005

Бркић, Н., \& Несторовић, М. (2011). Полне предрасуде младих: Шта се заиста променило [Sex prejudices of young people: What really changed]. Педагошка стварност. 57(3-4), 312-322.

Brooks, C., \& Bolzendahl, C. (2004). The transformation of US gender role attitudes: Cohort replacement, social-structural change, and ideological learning. Social Science Research, 33(1), 106-133. doi:10.1016/S0049-089X(03)00041-3 
Cao, L., \& Stack, S. (2010). Exploring terra incognita: Family values and prostitution acceptance in China. Journal of Criminal Justice, 38(4), 531-537. doi:10.1016/j.jcrimjus.2010.04.023

Cao, L., \& Selman, D. (2010). Children of a Common Mother: Determinants of Social Liberalism in the United States and Canada. Sociological focus, 43(4), 311329. doi: $10.2307 / 41633867$

Cao, L., Lu, R., \& Mei, X. (2016). Acceptance of Prostitution and Its Socaial Determinants in Canada. International Journal of Offender Therapy and Comparative Criminology, 1-20. doi:10.1177/0306624X15609920

Cassidy, M. L., \& Warren, B. O. (1996). Family employment status and gender role attitudes. Gender \& Society, 10(3), 312-329. doi: 10.1177/089124396010003007

Cool, J. (2004). Prostitution in Canada: An overview. Ottawa, Ontario: The Parlamentary Information and Research Service of the Library. Доступно на http://www.publications.gc.ca/collections/Collection-R/LoPBdP/PRBe/PRB0443-e.pdf, приступљено 8. 7. 2017.

Cosby, A., May, D., Frese, W., \& Dunaway, G. R. (1996). Legalization of crimes against the moral order. Deviant Behavior, 17, 369-389. doi: http://dx.doi.org/ 10.1080/01639625.1996.9968036

Cotton, A., Farley, M., \& Baron, R. (2002). Attitudes Toward Prostitution and Acceptance of Rape Myths. Journal of Applied Social Psychology, 32, 17901796. doi: 10.1111/j.1559-1816.2002.tb00259.x

Cree, V. E., \& Dean, J. S. (2015). Exploring social work students' attitudes towards feminism: opening up conversations. Social Work Education, 34(8), 1-18. doi: http://dx.doi.org/10.1080/02615479.2015.1081884

Davis, N. J., \& Robinson, J. (1991). Men's and women's consciousness of gender inequality: Austria, West Germany, Great Britain, and United States. American Sociological Review, 56, 72-84. doi: 10.2307/2095674

Докмановић, М. (2012). Родна равноправност и јавна политика [Gender Equality and Public Politics]. Суботица: Женски центар за демократију и родну равноправност. Доступно на http://www.e-jednakost.org.rs/kurs/kurs/download/ rodnaravnopravnostijavnapolitika.pdf, приступљено 7. 8. 2017.

Draženović, M. (2013). Prostitucija i sociokulturni aspekti zakonske regulacije prostitucije (u Hrvatskoj) [Prostitution and sociocultural aspects of legal regulation of prostitution (in Croatia)]. Neobjavljeni diplomski rad. Filozofski fakultet, Zagreb.

Ђурић-Кузмановић, Т. (2010). Регулатива вс. стварност у Србији - Родна равноправност, економија и држава [Regulatory vs. Reality in Serbia Gender Equality, Economy and State]. ТЕМИДА, 13(3), 69-82. Доступно на http://www.vds.org.rs/File/Tem1003.pdf, приступљено 8. 7. 2017.

Џамоња-Игњатовић, Т., Жегарац, Н., Поповић, Д., \& Духачек, Д. (2009). Истраживање ставова према родној равноправности у систему високошколског образовања [Research of Attitudes Towards Gender Equality in the System of Higher Education]. Годишњак Факултета политичких наука, 3(3), 695-709. Доступно на http://test.fpn.bg.ac.rs/wp-content/uploads/2010/ 05/41-dr-Tamara-D\%C5\%BEamonja-Ignjatovi\%C4\%87-dr-Nevenka-\%C5\% BDegarac-dr-Dragana-Popovi\%C4\%87-dr-Da\%C5\%A1a-Duha\%C4\%8DekIstra\%C5\%BEivanje-stavova-prema-rodnoj-ravnopravnosti-u-visoko\%C5\% A1kolskom-obrazovanju.pdf, приступљено 8. 7. 2017.

Haslanger, S., Tuana, N., \& O'Connor, P. (2012, November 28). Topics in Feminism. Retrieved from Stanford Encyclopedia of Philosophy: https://plato.stanford.edu/ entries/feminism-topics/ 
Inglehart, R., Nevitte, N., \& Basanez, M. (1996). The North American trajectory. New York: NY: Aldine de Gruyter.

Jakobsson, N., \& Kotsadam, A. (2009). What explains attitudes toward prostitution? Working Papers in Economics. Доступно на https://andreaskotsadam.files. wordpress.com/2010/06/prost.pdf, приступљено 8. 7. 2017.

Jakobsson, N., \& Kotsadam, A. (2011). Gender Equity and Prostitution:An Investigation of Attitudes in Norway and Sweden. Feminist Economics, 17(1), 31-58. doi: http://dx.doi.org/10.1080/13545701.2010.541863

Jóhannsdóttir, N. K. (2009). Patriarchy and the Subordination of Women from a Radical Feminst Point of View. Haskoli Islands: Feminist Study and Cultural Study, Siggilum Universitatis. Доступно на https://skemman.is/bitstream/ 1946/3017/1/Nina_Katrin_Johannasdottir_fixed.pdf, приступљено 8. 7.2017.

Константиновић-Вилић, С., Николић-Ристановић, В., \& Костић, М. (2009). Криминологија [Crminology]. Ниш - Горња Топоница: Пеликан принт.

Månsson, S. (2004). Men's practices in prostitution and their implications for social work. U S. Månsson, \& C. Proveyer, Social Work in Cuba and Sweden: Achievements and Prospects (str. 138-156). Göteborg/Havanna: Department of Social Work/Department of Sociology. Доступно на http://prostitution.procon. org/sourcefiles/mens-practices-in-prostitution-and-their-implications-forsocial-work.pdf, приступљено 8. 7. 2017.

May, D. C. (1999). Tolerance of nonconformity and its effect on attitudes toward the legalization of prostitution: A multivariate analysis. Deviant Behavior, 20(4), 335-358. doi: 10.1080/016396299266443

Мијатовић, М. (2008). Жене између приватног и јавног [Women between Private and Public]. У: А. Захаријевић (Ур.). Неко је рекао феминизам? (стр. 368383). Нови Сад: Регионална канцеларија за југоисточну Европу. Доступно на https://rs.boell.org/sites/default/files/feminizam_2_gesamt_v3.pdf, приступљено 8. 7. 2017.

Милосављевић, М. (2003). Девијације и друштво [Deviation and Society]. Београд: Драганић.

Overall., C. (1992). Whats Wrong with Prostitution? Evaluating Sex Work. Signs. 17(4), 704-724.

Rhodebeck, L. A. (1996). The Structure of Men's and Women's Feminist Orientations: Feminist Identity and Feminist Opinion. Gender and Society, 10(4), 386-403. doi:10.1177/089124396010004003

Sawyer, S., Metz, M. E., Hinds, J. D., \& Brucker, R. A. (2001). Attitudes towards prostitution among males: A "Consumers' report". Current psychology, 20(4), 363-376. doi: 10.1007/s12144-001-1018-Z

Schulze, E., Novo Canto, S. I., Mason, P., \& Skalin, M. (2014). Policy department Citizens rights and constitutional affairs: Sexual exploitation and prostitution and its impact on gender equality. Brussels: Europian Parliament. Доступно на http://www.europarl.europa.eu/RegData/etudes/etudes/join/2014/493040/IPOLFEMM_ET(2014)493040_EN.pdf, приступљено 8. 7.2017.

Службени гласник РС (2016). Национална стратегија за родну равноправност за период од 2016. до 2020. године са Акционим планом за период од 2016. до 2018. године [National Strategy for Gender Equality for the Period from 2016. to 2020. with the Action Plan for the Period from 2016. to 2018.]. Београд: Службени гласник РC, 4/16. Доступно на http://aler.rs/files/ NACIONALNA_STRATEGIJA_za_rodnu_ravnopravnost_za_period_od_201 6_do_2020_godine_sa_akcionim_planom_za_period_od_2016_do_2018_god ine_S1_gl_RS_br_4_2016.pdf, приступљено 8. 7. 2017. 
Службени гласник PC (2009). Закон о забрани дискриминације [Law on the Prohibition of Discrimination]. Београд: Сл. гласник PC, 22/09. Доступно на http://www.paragraf.rs/propisi/zakon_o_zabrani_diskriminacije.html, приступљено 8. 7. 2017.

Службени гласник РС (2016). Закон о јавном реду и миру [Law on Public Order and Peace]. Београд: Сл. Гласник РС, 6/16. Доступно на http://www.paragraf.rs/ propisi/zakon_o_javnom_redu_i_miru.html, приступљено 8. 7. 2017.

Soo Chon, D. (2015). Gender Equality, Liberalism and Attitude Toward Prostitution: Variation in Cross-National Study. Journal of Family Violence, 30(7), 827838. doi:10.1007/s10896-015-9713-y

Stack, S., Adamczyk, A., \& Cao, L. (2010). Survivalism and public opinion on criminality: A Cross-National Analysis of Prostitution. Social Forces, 88(4), 1703-1726. doi: 10.1353/sof.2010.0029

Стојаковић, Г., \& Петровић-Ранитовић, Т. (2013). Проституиија у Србији Једно од могућих лииа [Prostitution in Serbia - One of the possible faces]. Нови сад: Удружење грађана „С.Т.Р.И.К.Е.”

Tallichet, S., \& Willits, F. (1986). Gender-Role Attitudes Change of Young Women Influential Factors from a Panel Study. Social Psihology Quarterly, 49, 219227. doi: $10.2307 / 2786804$

Toller, P. W., Suter, E. A., \& Trautman , T. C. (2004). Gender role identity and attitudes toward feminism. Sex Roles, 51(1-2), 85-90. Doi: 10.1023/B:SERS. 0000032316.71165 .45

Захаријевић, А. (2008). Кратка историја спорова: Шта је феминизам? [Short history of disputes: What is feminism]. У: А. Захаријевић (Ур.). Неко је рекао феминизам? (стр. 384-415). Нови Сад: Регионална канцеларија за југоисточну Европу. Доступно на https://rs.boell.org/sites/default/files/ feminizam_2_gesamt_v3.pdf, приступљено 20.9. 2017.

Weitzer, R. (2000). Sex for sale: Prostitution, pornography, and the sex industry. New York: Routledge.

Welzel, C., \& Inglehart, R. (2005). Liberalism, Postmaterialism, and the Growth of Freedom. International Review of Sociology, 15(1), 81-108. doi: 10.1080/ 03906700500038579

Welzel, C., Inglehart, R., \& Hans-Dieter, K. (2003). The theory of human development: A cross-cultural analysis. European Journal of Political Research, 42(3), 341-379. doi: 10.1111/1475-6765.00086

World Economic Forum. (2016). The Global Gender Gap Report. Geneva: World Economic Forum. Доступно на http://www3.weforum.org/docs/GGGR16/ WEF_Global_Gender_Gap_Report_2016.pdf, приступљено 8. 7. 2017.

Wu, B., \& McCaghy, C. H. (1993). Attitudinal determinants of public opinions toward legalized pornography. Journal of criminal, 21(1), 13-28. doi:10.1016/00472352(93)90003-6 


\title{
ATTITUDES OF YOUNG PEOPLE IN SERBIA ABOUT PROSTITUTION, GENDER EQUALITY AND FEMINISM IN 2016
}

\author{
Dragica Bogetić, Jelena Mitrović, Sandra Nikolić \\ University of Belgrade, Faculty od Special Education and Rehabilitation, Belgrade, \\ Serbia
}

Summary

Within the context of unregulated rights of women engaged in prostitution this paper analyses this phenomenon from social, gender and political aspects. Considering legislation in countries with high index of gender equality and through the prism of research conducted in the world and in Serbia, the final outcome was, above all, bringing into relation the phenomenon of gender equality with prostitution.

The conducted research was aimed to examine social and demographic correlates of attitudes of young people in Serbia about prostitution, gender equality and feminism. The first task was to check metric characteristics of three scales, where two were co-opted from former research (gender equality and feminism; (Džamonja-Ignjatović, Žegarac, Popović, \& Duhaček, 2009), while one scale was constructed for the purpose of this research (the scale of attitudes about prostitution). The second task was to examine whether and in which way inspected attitudes depend on gender, place of growing up and age of participants. Finally, we believed that it would be important to check in which relation these three attitudes are and whether their connectedness with basic variables of sexual behaviour exists, such as age of the first sexual intercourse and the number of sexual partners.

We wished to research the existence of connectedness between advocating for a better life of women generally and in prostitution by questioning the connectedness of attitudes toward prostitution (advocating for better regulations in the country, more adequate health care and social protection of women in prostitution, minor social stigma and social distance) and the attitude toward gender equality and feminism.

The sample for research was 1114 participants (67.6\% female and $32.4 \%$ male). The average age of participants was 22.4 years $(\mathrm{SD}=2.59)$.

The results point to the fact that male and female participants are different in all three scales of attitudes. The biggest difference was detected in the scale of feminism and in favour of female participants $(\mathrm{d}=0.76)$.

Similar to that, female participants have a more positive attitude about gender equality in relation to male participants $(\mathrm{d}=0.39)$. In the scale of attitudes about prostitution we registered a completely opposite tendency. Namely, in this case, a significantly more positive attitude was registered with male participants $(\mathrm{d}=0.34)$. Also, the results point that there is a positive correlation of attitudes toward gender equality and prostitution, and the difference between male and female participants in regard to the attitudes about prostitution was far more noticeable in smaller than in bigger cities.

More and more negative attitudes of males in bigger cities may be perceived as an indicator of a higher grade of understanding of social and economic circumstances in which women had been brought to the position of engaging within unregulated prostitution including all the risks such an activity provides. On the other hand, more and more positive attitudes of women about prostitution in bigger cities may be realised as an expression of emancipation of traditional models of gender roles. In accordance with this is the finding of 
the correlation between the attitude toward prostitution and a number of sexual partners, including different models registered between the genders of participants.

The highest value of this work would be the rise of awareness of scientific and professional public about the importance of adopting equal discourse which would put in the foreground the introduction of women's right element in prostitution and different systemic regulations in Serbia. In that respect, further examination of the attitudes about systemic solutions, chances and challenges in the field of prostitution would provide a significant input of research to this subject. 